\title{
‘ADAM LAY YBOUNDEN’: A MARIAN FELIX CULPA
}

\author{
F R A N K G. B O S M A N
}

\begin{abstract}
The 15th-century poem 'Adam lay ybounden' presents a 'folk version' of the paradoxical theology of the notion of felix culpa, Adam's 'happy fault' by which the Incarnation of God in Jesus of Nazareth was unintentionally provoked. The poem is simple in its vocabulary, but elaborate in its invocation of theological notions such as the descensus Christi as inferos, the felix culpa and the necessarium Adae peccatum, both from the Easter prayer of the 'Exsultet', focussing on the role of Mary within the economy of salvation rather than on Christ's. While having been researched only fragmentarily in the past, in this article, the theological content of this poem is analysed integrally for the first time.
\end{abstract}

\section{Keywords:}

Adam lay ybounden; Middle-English poetry; Mariology; Felix culpa; Descensus Christi ad inferos; Forbidden fruit; Primordial sin

DOI: $10.14712 / 23363398.2020 .62$

Blessed be the time that the apple was taken therefore we may sing: thanks to the Lord.

$\mathrm{I}_{\mathrm{n}}$ a unique manuscript, Sloane 2593, held by the British Library, a curious little poem from the beginning of the 15th century has been preserved. The poem is known from its first thee words as 'Adam lay ibowndyn', or in a slightly modernised spelling, as 'Adam lay ybounden'. The poem, crammed in between rather vulgar songs about 
the size of one's penis and songs posing a riddle to its listeners, 'Adam lay ybounden' succeeds in simultaneously being plain and simple in its vocabulary, while invoking complex theological notions and themes ranging from the descensus Christi ad inferos to felix culpa.

The poem, in various textual modernisations, has been popularised in our times by numerous musical settings, which are still performed today. 'Adam lay ybounden' has been used by composers, such as Peter Warlock (1923), John Ireland (1956), Boris Ord (1957), Philip Ledger (1980), Howard Skempton (2001), Giles Swayne (2009) and Robert Edward Smith (2018). Especially famous is Benjamin Britten's interpretation of the poem, which he included, as 'Deo Gracias', in his 'Ceremony of the Carols' from 1942.

The poet rejoices in the paradoxical idea that humankind should be thankful that Adam committed the first sin, eating the forbidden fruit of paradise: 'Blessed be the time that the apple was taken / therefore we may sing: thanks to the Lord.' The reasoning is astute and supple: 'Had the apple not been taken / our Lady would never have been heaven's queen.' If Adam had not sinned, God would never have been incarnated in Jesus, and Mary would never have become the Mother of God. It is a theological and 'Marian' turnaround reminiscent of the famous phrases of the Easter Exsultet, O certe necessarium Adae peccatum / O felix culpa ('O truly necessary sin of Adam / O happy fault'). ${ }^{1}$

Although 'Adam lay ybounden' has been incorporated in a large number of anthologies on English lyric from the Middle Ages and has been briefly discussed by a variety of scholars, it was mostly reflected with regard to the poetic and not the theological elements, as we will discuss later on in this article. The theological complexity of this 'folk song' has never been fully analysed systematically. ${ }^{2}$ In order to achieve a theological analysis of 'Adam lay ybounden', my analysis will be primarily synchronic. ${ }^{3}$ This implies that I do not attempt to argue what the real author has intended with his poem (known as the 'intentional fallacy'), but that I wish to make an analysis of the actual theological

Victor Haines, 'Felix Culpa,' in A dictionary of Biblical tradition in English literature, ed. David Jeffrey (Grand Rapids: William B. Eerdmans Publishing, 1992), 274-275; Jay Ruud, Encyclopedia Of Medieval Literature (New York: Facts on File, 2006), 6-7.

2 James Dean, 'Adam lay bound,' in The facts on file companion to British poetry before 1600, ed. Michelle Sauer (New York: Facts on File, 2008), 1.

3 Archibald van Wieringen, 'Methodological developments in Biblical exegesis. Author test - reader,' Analecta of the UCU (forthcoming). 
meaning of the present text and its intertextual relationships to other texts from Bible and tradition. ${ }^{4}$

In this article, I want to do a full theological examination of the medieval poem, considering it as an example of Marian folk spirituality, that is, a syncretic mixture of official ecclesiastical doctrines, on the one hand, and an amalgam of stories, legends, and poems on the other, which was distributed not so much by clergymen, but primarily by minstrels and story-tellers. ${ }^{5}$

In the first section, I will introduce the poem 'Adam lay ybounden', while the later sections are devoted to the four strophes respectively, focussing on the different theological themes like the descensus Christi ad inferos, the forbidden fruit, the felix culpa, and the portrayal of Mary as the new Adam. I will argue that 'Adam lay ybounden' could be considered as a 'commoner's' (völkerisch) version of the felix culpa doctrine from Christian theological tradition, focussing on the role of Mary within the economy of salvation, rather than on Christ's. ${ }^{6}$

All quotations from the Bible are taken from the New American Standard Bible (NASB) translation.

\section{The song ‘Adam lay ybounden’}

The poem 'Adam lay ybounden' is found in Sloane Manuscript 2593 (folio 11), held by the British Library. The manuscript seems to be an amalgam of reverent religious songs, like 'I syng of a mayden' and 'Lullay, mone liking', both in honour of Mary, and more vulgar songs like 'I have a gentil cock'. 'Adam lay ybounden' is preceded by 'Omen gentes plaudit', which initially seems to refer to Psalm 47, but is actually a drinking song, and is succeeded by 'I have a young sister', an erotic riddle disguised in the form of a nursery rhyme. ${ }^{7}$ The poem was written at the beginning of the 15th century, and is probably native to the region of East Anglia, more

\footnotetext{
Graham Allen, Intertextuality (London: Routledge, 2000).

5 Robert Wuthnow, Meaning and moral order. Explorations in cultural analysis (Berkeley: University of California Press, 1987), 187-188.

${ }_{6}$ For a technical analysis of the qualities of the poem's lyrics, see: Stephen Manning, Wisdom and number. Towards a critical appraisal of the Middle English religious lyric (Lincoln: University of Nebraska Press, 1962), 6-7; Edmund Reiss, The art of the Middle English lyric. Essays in criticism (Athens: University of Georgia Press, 1972), 138-142; and Thomas Duncan, 'The Text and Verse-Form of "Adam Lay I-Bowndyn",' The Review of English Studies 38, n. 150 (1987): 215-221, doi: 10.1093/res/XXXVIII.150.215.

7 F. Padelford, 'Transition English song collections,' in Cambridge history of English literature 2. The end of the Middle Ages, eds. A. Ward and A. Waller (Cambridge:
} 
specifically Norfolk, as Kathleen Palti has argued. ${ }^{8}$ Her transcription of the Middle-English text from Sloane 2593 runs as follows. ${ }^{9}$

1. Adam lay ibowndyn bowndyn in a bond fowr' bowsand wynter bowt he not to long

2. And al was for an appil An appil pat he tok as clerkis fyndyn wretyn in her' book

3. Ne hadde pe appil take ben be appil taken ben ne hadde neuer our lady a ben heuene qwen

4. Blyssid be be tyme pat appil take was perfor' we mown syngyn deo gracia $^{10}$

\section{In modern English translation, the text would read something resembling this.}

1. Adam lay bounden, bounden in a bond four thousand winters, he thought no to(o) long ${ }^{11}$

2. And all was for an apple, an apple that he took as clerics find written, (written) ${ }^{12}$ in their book

3. Had the apple not been taken, the apple been taken our Lady would never have been heaven's queen

4. Blessed be the time that the apple was taken therefore we may sing: thanks to the Lord

Cambridge University Press, 1908) 387; and Douglas Gray, Later medieval English literature (Oxford: Oxford University Press, 2008), 368.

8 Kathleen Palti, 'Synge we now alle and sum. Three Fifteenth-Century collections of communal song. A study of British Library, Sloane MS 2593; Bodleian Library, MS Eng. poet. e.1; and St John's College, Cambridge, MS S.54. Part I: Thesis' (doctoral thesis, University College London, London, 2008), 71-73 and 104-123.

9 Kathleen Palti, 'Synge we now alle and sum. A study of British Library, Sloane MS 2593; Bodleian Library, MS Eng. poet. e.1; and St John's College, Cambridge, MS S.54, part II: Appendices' (doctoral thesis, University College London, London, 2008), 389.

10 The second of the two Latin words is misspelled as gracia instead of gratias.

11 The text can be translated as either 'he thought not too long', meaning that Adam thought four thousand years as not being too long a wait for salvation, or 'he thought not to long', meaning that Adam, for four thousand years, did not dare to long for salvation. Both options are feasible within the larger framework of the poem. Maybe the ambiguity of the text was intended, but we can only speculate about that.

12 Duncan suggested including a second 'wretyn' to repair the otherwise broken metric, a problem already noticed, but not solved, by Reiss. See: Duncan, 'Text,' 215-221 and Reiss, 'Art,' 139. I have chosen to follow his suggestion in my translation of the poem. 
The poem is included in numerous anthologies concerning medieval English lyric. Sometimes the poem is only mentioned without any further comment or analysis..$^{13}$ Other ones give short descriptions of the poem, though not necessarily positive ones.

Theodore Silverstein summarises quite aptly that 'Adam lay ybounden' is essentially a 'reversal of expectations (...) in a brief poem of praise for Mary', connected to the theme of the felix culpa 'joyously acclaimed on Easter Eve'. ${ }^{14}$ Paul Morris and Deborah Sawyer echo this sentiment, identifying the poem's theme as 'a type of "fall upwards"" ${ }^{15}$ Rosemary Woolf praises the poem for its lyrical structure, which is even appealing to modern readers, and points to several other medieval folk poems dedicated to Mary, that mention the idea of felix culpa, like 'A salutation to the virgin' and 'Regina celi letare'. ${ }^{16}$ Marina Warner, in her monograph on Mariology, even identifies the anonymous author as a 'poet of genius'. ${ }^{17}$

The poem presents, indeed, a 'Marian' version of the felix culpa theology. Adam's sin is not so much forgivable or 'happy' because it resulted in the Incarnation of Christ, but because it made Mary his mother and therefore the queen of heaven. 'Adam lay ybounden' is not the only poem occupied with this theme. Lydgate's 'Regina Celi Letare' and 'On the image of the pity' do likewise, just as the anonymous 'Haile be thou' and 'Si pro peccato'. ${ }^{18}$

Edmund Reiss is more ambivalent in his qualification. According to him, the poem is 'on the surface, a naïve, unsophisticated ballad-like piece' that, nevertheless, 'still has a compelling quality that

13 Edmund and Frank Sidgwick, Early English lyrics amorous, divine, moral \& trivial (London: Bullen, 1926), 102; and Thomas Wright, Songs and carols from a manuscript in the British Museum of the 15th century (London: T. Richards, 1861), 32-33.

14 Theodore Silverstein, English lyrics before 1500 (Evanston: Northwestern University Press, 1971), 100.

15 Paul Morris, 'A walk in the garden. Images of Eden,' in A walk in the garden. Biblical iconography and literary images of Eden, eds. Paul Morris and Deborah Sawyer (Sheffield: Sheffield University Press, 1992), 33.

16 Rosemary Woolf, The English religious lyric in the middle ages (Oxford: Clarendon Press, 1998), 290; Carleton Brown, Religious lyrics in the XVth century (Oxford: Clarendon Press, 1939), 30-33; and John Lydgate, The minor poems of John Lydgate (London: Oxford University Press, 1911), 293.

17 Marina Warner, Alone of all her sex. The myth and cult of the virgin Mary (Oxford: Oxford University Press, 1976), 62.

18 Lydgate, 'Minor poems,' 293 and 298; Brown, 'Lyrics,' 30; Haines, 'Fall,' 13 (quoted); Gary Waller, The Virgin Mary in late medieval and early modern English literature and popular culture (New York: Cambridge University Press, 2001), 71. 
stems from its simple language and the combination of its rhythm and sounds'. ${ }^{19}$

Charlton Brown more or less disqualifies the theological dimension of the poem by firstly identifying 'Adam lay ybounden' together with 'Maiden Makeles' and 'The Child that Died for Us' as 'touch[ing] elbows with the popular ballads', and secondly contrasting those three with other texts in Sloane, that 'are sophisticated in tone and are characterised by verbal conceits and clever paradox', that 'owe no kinship to the ballad, but look forward, instead, to the poetry of the metaphysical school'. ${ }^{20}$

These and other scholars have identified multiple theological themes in the poem, which will be systematically addressed by a verse-by-verse synchronic analysis in the following sections.

\section{Strophe I: The Descensus Christi ad inferos}

In the first strophe, the figure of Adam is introduced and qualified as 'bounden in a bond' for a period of 'four thousand winters'. Depending on the interpretation of the Middle-English phrase 'powt he not to long', Adam himself seems either unimpressed by the number of years, possibly relative to his insight of the magnitude of his own sinful action damning all of humankind, or is surprised because of the so desired, but still unexpected, the arrival of his redemption. ${ }^{21}$

The 'bonds' mentioned in the text are a reference to metaphorical shackles with which Adam is said to have been held in imprisonment in the underworld since his regretful transgression of God's commandment (Genesis 2:17), but also to a kind of contract, or even 'covenant', God is held to have made between fallen humankind and himself in order to ensure its eventual redemption and return to paradise. ${ }^{22}$ While the covenant metaphor could be taken from Biblical vocabulary - found both in the Hebrew Bible (for example Genesis 9:9) and in the New Testament (emphatically found in Hebrews 9) - the idea that Adam's fall could have caused or even provoked such a 'deal' involving God's Incarnation in Jesus to atone for Adam's sins (and for those of all humankind collectively), is certainly not.

19 Reiss, 'Art,' 139.

20 Brown, 'Religious lyrics,' xxv.

21 See footnote 8.

22 Dean, 'Adam,' 1. 
The idea that Adam's sin - the consumption of the forbidden fruit was paradoxically something humankind could retrospectively be happy about, a notion commonly referred to as felix culpa, will be addressed in more detail later in this article. The notion that Adam was 'located' somewhere between his natural death after his expulsion from Paradise and Jesus' death and resurrection is known in the Christian tradition. ${ }^{25}$ Adam's soul and those of the pious from the Biblical history were thought to be collected in the limbus partum ('the limbo of the patriarchs') to await the salvific arrival of the Christ. The liberation of those souls from Limbo is known as the descensus Christi ad inferos, literally 'Christ's descent into the underworld', in English also known as the 'harrowing of hell'. ${ }^{24}$ The harrowing itself is thought to have taken place between Jesus' death on the cross and his resurrection from the grave three days later, although no sources of such an event are present in the New Testament. ${ }^{25}$

In the 'Exsultet', the Easter prayer (originating from the end of the 4 th, beginning of the 5th century), which features the felix culpa and the necessarium Adae peccatum (see below), phrases can also be found about the harrowing of hell. ${ }^{26}$

Haec nox est, in qua, destructis vinculis mortis,

Christus ab inferis victor ascendit.

$(\ldots)$

$\mathrm{O}$ vere beata nox,

quae sola meruit scire tempus et horam, in qua Christus ab inferis resurrexit!

Reiss, 'Art,' 140.

24 Marcel Sarot, 'The scope of redemption on finding meaning in Christ's descent into hell,' in The Apostles' Creed. 'He descended into hell,'eds. Marcel Sarot and Archibald van Wieringen (Leiden: Brill, 2018), 185-206.

25 Archibald van Wieringen, 'Descent into the netherworld. A biblical perspective,' in idem, 9-32.

26 Guido Fuchs and Hans Weikmann, Das Exsultet. Geschichte, Theologie und Gestaltung. der österlichen Lichtdanksagung (Regensburg: Verlag Friedrich Pustet, 1992), 61 and 71-72. 
In English translation:

This is the night, in which, destroying the chains of death,

Christ has risen from the underworld victoriously.

$(\ldots)$

$\mathrm{O}$, truly blessed night,

that earned alone to know time and hour,

in which Christ rose from the underworld.

The Easter night is celebrated as the moment in which the vincula mortis, the 'chains of death' are broken (the same bonds that keep Adam 'ybounden' in the first strophe of the poem) by Christ who triumphed not only over his own death but over the death of all the faithful from the past, present, and future, through descending into and ascending from the Limbo of the pre-Christian saints.

The number of years Adam had to wait until he was freed from the underworld mentioned in the poem, 'four thousand winters', or 4000 years, seems somewhat randomly chosen initially. There is a number of possible interpretations. Reiss argues - simply - that it is a reference to the four weeks of the Advent, the liturgical preparational period for Christmastide. ${ }^{27}$ Since many commentators and editors have classified 'Adam lay ybounden' mainly as a nativity song, probably because of the physical proximity of other songs more explicitly connected to Christmas contained in the Sloane manuscript, and since it (therefore) has been frequently performed within the Christmas repertoire of the English choir tradition, among others in Britten's aforementioned 'Ceremony of the Carols', the association is likely.

Patrick Diehl argues that several numbers concerning the time between the Fall and Redemption circulated in medieval German, French, Italian, and English literature and poetry, ranging from 4000 via 5000 to $5200 .^{28}$ The last one is supposed to be a reference to a total of 52 weeks in a regular year. ${ }^{29}$ James Dean opts for a slightly different interpretation, relating the four millennia of 'Adam lay ybounden' to the idea of the sex aetates mundi, the notion of the 'six ages of the world' as

27 Reiss, 'Art,' 140.

28 Patrick Diehl, The Medieval European religious lyric. An ars poetica (Berkeley: University of California Press, 1985), 155.

29 Diehl, 'Lyric,' 156. 
described, among others, by Augustine of Hippo in his De Catechizandis rudibus (par. 22)..$^{30}$

Brian Murdoch suggests yet another possible source for the number of four thousand years in the poem: the apocryphal Gospel of Nicodemus. ${ }^{31}$ The Gospel of Nicodemus, written in the 5th or 6th century, incorporates the 'Acts of Pilate' and the 'Christ's descent into Hell'. ${ }^{32}$ The Acts describe, among other things, John the Baptist preaching before the patriarchs in the limbus patrum. John serves as the last prophet of the 'Old Testament' since he is the only prophet who has seen and identified Jesus as the messiah (for example, John 1:29).

After a while, Seth - Adam's third son - re-tells an intriguing little story. When his father was ill, Seth had an encounter with an angel, who sent him back to Adam to tell him: 'after the completion of 5500 years from the creation of the world, the only-begotten Son of God shall become man and shall descend below the earth. ${ }^{93}$

Another possible option is provided by Douglas Gray, who suggests a connection to Dante's Divine Comedy. ${ }^{34}$ In canto xxvi of 'Paradiso' (lines 118-120), Adam reveals to Dante that his stay in Limbo lasted 4302 years. ${ }^{35}$ Again, the numbers are not precisely the same, but it is safe to say that, as Dean and Diehl have suggested, the 'divine arithmetic' should not be taken literally but spiritually, indicating God's meticulous planning on behalf of fallen humankind.

\section{Strophe II. The Forbidden Fruit}

The second strophe of the poem connects Adam's predicament - laying in bonds for four millennia - to his transgression, thus linking the crime with its punishment. The poet simply states that Adam took an apple, as 'clergymen found written in their book'. The combination of

30 Dean, 'Adam,' 2.

31 Brian Murdoch, Adam's grace. Fall and redemption in medieval literature (Woodbridge: Brewer, 2000), 12; and Brian Murdoch, The Medieval popular Bible. Expansions of Genesis in the Middle Ages (Cambridge: Cambridge University Press, 2003), 16.

32 J. Eliott, The apocryphal New Testament. A collection of apocryphal Christian literature in an English translation based on M.R. James (Oxford: Clarendon Press, 1993), 165.

33 Wilhelm Schneemelcher, The New Testament Apocrypha. Volume 1. Gospels and related writing (Louisville: Westminster John Knox Press, 1990), 523.

34 Douglas Gray, A selection of religious lyrics (Oxford: Clarendon Press 1975), 98.

35 Dante Alighieri, La divina commedia (The Divine Comedy). Paradiso (Bruckman: s.l., 2011), 570-571; Robert Durling, The divine comedy of Dante Alighieri (Oxford: Oxford University Press, 2011), 535. 
the identity of the forbidden fruit and the Bible, or the Vulgate more specifically in this instance, is interesting since the book of Genesis does not give any indication about what kind of fruit Adam was supposed to have left unconsumed. The identification of the fruit as an apple is, however, virtually universal in both medieval and modern literature, and is only challenged in scholarly circles. ${ }^{36}$ Intriguingly enough, the poem gives a hint as to where we can find the source of this odd identification: the clerics' book, that is, the Vulgate. ${ }^{37}$

First of all, the Latin word in the Vulgate for 'apple' and 'evil' is, in both instances, malum. And since there is no greater evil than Adam's primordial sin, damning all of the humankind within it, it is feasible to think of the unnamed fruit of Genesis as 'an apple'. ${ }^{38}$ However, there is more to it. In the Hebrew Bible, at least in its Latin translation, apples are connected to love and sexuality, especially in the Song of Solomon.

Like an apple tree [malum] among the trees of the forest, / so is my beloved among the young men. / In his shade I took great delight and sat down, / and his fruit was sweet to my taste. (Song of Solomon 2:3)

Sustain me with raisin cakes, / refresh me with apples [malis], / because I am lovesick. (Song of Solomon 2:5)

I said, 'I will climb the palm tree, / I will take hold of its fruit stalks.' / Oh, may your breasts be like clusters of the vine, / and the fragrance of your breath like apples [malorum]. (Song of Solomon 7:8)

One (Latin) verse from the Song of Solomon contradicts this positive association between love and apples, turning it into its opposite. The Vulgate translates the notoriously difficult verse 8:5 as: 'Sub arbore malo suscitavi te ibi corrupta est mater tua ibi violata est genetrix tua,' which can be translated as: 'Under the apple tree I have raised you up; there your mother was corrupted; there she was violated, your birth-mother.' The NASB gives something entirely different: 'Beneath

36 Murdoch, 'Bible,' 16-17.

37 John Speirs, Medieval English poetry. The non-Chaucerian tradition (London: Faber \& Faber, 1971), 65.

38 George. Scheper, 'Apple,' in A dictionary of Biblical tradition in English literature, ed. David Jeffrey (Grand Rapids: William B. Eerdmans, 1992), 50. 
the apple tree I awakened you; / there your mother was in labor with you, / there she was in labor and gave you birth.' The significant differences in the various translations, both modern and classical, are indicative of its difficulty.

From the perspective of the Vulgate, one can understand that the $s u b$ arbore malo, the tree under which bad things happened to an unnamed woman, a mother, is linked to the tree from Eden, under the branches of which Adam and Eve sinned for the first time. ${ }^{39}$ The correlation between apple, evil, love, and sexuality is a recurring theme in Christian theological tradition, especially in relation with the doctrine of original sin. ${ }^{40}$ The 'apple that Adam took' from the poem invokes not only the act of initial transgression on the part of Adam but also conjures up the whole corpus of Biblical texts, translations and interpretations linking Adam's sin with sex. The bondage from which Adam is finally rescued is not only a 'physical' one in the limbus patrum but also a moral one: saved from the bondage between sexual intercourse and the transmission of original sin.

One more element regarding the notion of the apple tree from Eden has to be dealt with. Within Christian theology, three trees have been associated with one another: two in Genesis, the Tree of Knowledge of Good and Evil and the Tree of Everlasting Life, and one in the gospels, the 'tree' of the cross. ${ }^{41}$ 'Adam lay ybounden' - again - takes this idea one step further. Adam's apple from the poem is not only substituted with the wood of the cross, but the two are morphed into one: the apple has become the reason for Christ's Incarnation, execution, and resurrection.

\section{Strophe III. The Heavenly Queen}

As Reiss has already observed, one significant figure is noticeably absent from the poem's narrative: Jesus Christ. ${ }^{42}$ The whole poem is

39 Murdoch, 'Bible,' 16.

40 James Gailey, Sex, war, and 'sin'. Humanity's path from the garden towards the city of a holy God (Eugene: Wipf and Stock, 2012), 73-76; Patricia Williams, Doing without Adam and Eve (Fortress Press: Minneapolis, 2000); Pier Franco Beatrice, The transmission of sin. Augustine and the pre-Augustinian sources (Oxford: Oxford University Press, 2013).

41 Réné Guénon, The symbolism of the cross (Gent: Sophia Perennis, 2004), 54-61; Alva Steffler, Symbols of the Christian faith (Grand Rapids: William B. Eerdmans, 2002), 125.

42 Reiss, 'Art,' 139. 
dedicated to the Virgin Mary, who is praised as the 'heavenly queen' and as the whole blessed outcome of Adam's felix culpa. If Adam had not taken the apple, Mary would never have become the mother of Jesus, and - by extension - the Mother of God. And it is through her that the unmentioned Jesus Christ was born, who would eventually break Adam's bonds, and - by equal extension - the bonds of sin that bound all of humankind.

The transition from the notion of the apple and its connotations of the forbidden fruit (sex) from strophe II to the focus on Mary's role in the economy of salvation in strophe III is all the more interesting because of Mary's special theological status in regard to original sin and to human sexuality. In Roman Catholic tradition, Mary is considered to be semper virgo, having maintained her virginity before, during, and after giving birth to Jesus. ${ }^{43}$ Furthermore, even though the idea of Mary's immaculate conception was only officially and dogmatically defined in Pope Pius IX's Ineffabilis Deus (1854), the veneration of Mary as such holds much older papers. ${ }^{44}$ Both Marian dogmas work together to establish Mary as being as far removed from Eve as possible, especially concerning sex and sin, and are, at the same time, the result of this estrangement.

The change of focus in 'Adam lay ybounden' from Jesus to Mary classified as 'fresh' by Reiss - is part of both a more significant theological development to juxtapose Jesus/Mary with Adam/Eve, and a slightly lesser one involving the conception of a 'Marian felix culpa'..$^{45}$ As Haffner summarises: 'The Patristic writers of East and West referred to Mary as the "new Eve", who co-operated with Christ the "new Adam". ${ }^{46}$ This re-focus of the felix culpa on Mary is found throughout the medieval religious lyrical tradition. ${ }^{47}$

The contrast between Eve and Mary is also present in the fruit they present. Eve is the presenter of the forbidden fruit, as we have established earlier in this article, that produces death, while Mary 'produces' the new Adam, the fruit of her womb, that provides eternal life. ${ }^{48}$ It is

43 Donald Calloway, 'Theology of the body and Marian dogmas,' in The virgin Mary and theology of the body, ed. Donald Calloway (West Chester: Ascension Press, 2007).

${ }_{44}$ Kathleen Coyle, Mary in the Christian tradition. From a contemporary perspective (Quezon City: Claretian Publications, 2006), 35.

45 Murdoch, 'Adam's grace,' 12.

46 Paul Heffner, The mystery of Mary (Chicago: Hillenbrand Books, 2004), 75.

47 Woolf, 'Lyric,' 291.

48 Sally Cunneen, In search of Mary. The woman and the symbol (New York: Ballantine Books,1996), 63-69. 
a far, but noticeable, echo of Elizabeth's greeting to Mary, 'blessed are you among women, and blessed is the fruit of your womb' (Luke 1:42), anchored in Roman Catholic piety by its inclusion in the prayer 'Hail Mary' as 'blessed art thou amongst women, and blessed is the fruit of thy womb, Jesus'. ${ }^{49}$

Since the chastity of Mary and its role in the economy of salvation is so important and since 'Adam lay ybounden' is connected to the idea of felix culpa, as it is expressed in the 'Exsultet' prayer, it is interesting to point out an old, but now disused part of that prayer involving an appraisal of bees, responsible for the production of the waxen Easter candles, because of their supposed chastity ${ }^{50}$

Nearing the end of the 'Exsultet', the candles are blessed, ignited 'for God's honour, a fire into many flames divided, yet never dimmed by sharing of its light'. ${ }^{51}$ The light, the prayer continues, is 'fed by melting wax' (alitur liquantibus ceris), and 'drawn out by mother bees' (apis mater eduxit). Originally, the prayer would have continued with a praising of the bees, but since the 16th century, it has disappeared from the official liturgical texts. ${ }^{52}$ Taking direct inspiration from Virgil's fourth Georgic ode (83 and 162-164), the texts described the honey-centred life of the bees..$^{53}$ The bees' appraisal ends with the following exclamation, linking the bees to Mary:

$O$ vere beata et mirabilis apis, cuius nec sexum masculi violant, foetus non quessant, nec filii destruunt castitatem; sicut sancta concepit virgo Maria, virgo peperit et virgo permansit.

$\mathrm{O}$ truly blessed and wonderful bee. Their males do not violate their sexual organs. Their unborn ones do not disturb the sexual organs. ${ }^{54}$ Their children do not destroy their chastity. Just like the holy Maria has conceived as a virgin, has brought forth as a virgin, and has remained a virgin. ${ }^{55}$

\footnotetext{
Dean, 'Adam,' 2.

50 Anna Taylor, Epic lives and monasticism in the Middle Ages, 800-1050 (Cambridge: Cambridge University Press, 2013), 233.

51 If not stated otherwise, the English text of the 'Exsultet' is taken from: The Roman Missal, London 2010.

52 Fuchs, 'Exsultet,' 94.

53 Thomas. Kelly, The Exsultet in southern Italy (Oxford: Oxford University Press, 1996), 51.

${ }^{54}$ Another possible but less comprehensive translation of this section would be: 'They do not disturb their unborn ones.'

55 I would like to thank my friend Bas Suikerbuik for his help with the translation.
} 
Based on the idea, predating Christianity itself, that bees do procreate without having sex with one another, the Church Fathers were keen on identifying them as a metaphor for the virginal Mother of God. ${ }^{56}$ So again the idea is promoted that it is was apt that Mary should give birth to Jesus Christ, indeed because she was thought to have not been tainted by either Adam's original sin or the sexual intercourse associated with it: her fruit was pure and eternal, where Eve's was tainted and temporal. Interestingly enough, 'Adam lay ybounden' does not simply repeat this pattern by linking Adam to Christ and Eve to Mary, but juxtaposes Adam to Mary. This is both an indication of the 'Marian turn' in medieval theology, and surprisingly 'feminist' in nature since it re-focusses the guilt of the fall away from the female (Eve) to the male (Adam). ${ }^{57}$

\section{Strophe IV. The Felix Culpa}

The fourth and final strophe marks the culmination of the dramatic movement. The poet blesses Adam and his transgression: 'deo gracia'. The insertion of a Latin phrase, although not spelled entirely correctly, in combination with the accompanied phrase 'therefore we may sing, conjures up a liturgical discourse. The benediction Deo gratias is well known within and without the Roman Catholic liturgy of medieval times, and it has been used, at least since the 10th century, as a responsorial to the threefold Lumen Christi ('the light of Christ') prior to the 'Exsutet'. ${ }^{58}$ But even without this liturgical reference, virtually all commentators of 'Adam lay ybounden' connect the poem to the notion of the felix culpa from the great Easter hymn.

The whole pointe of the poem is the paradoxical idea that we may rejoice in Adam's original sin, because it resulted in, triggered, or provoked the Incarnation of God in Jesus through Mary. As observed before, 'Adam lay ybounden' focusses on Mary rather than on Christ, but the reasoning is the same: Adam resulted in Christ, sin resulted in salvation. In the 'Exsultet', it is formulated as:

56 Fuchs, 'Exsultet,' 94.

57 Tina Beattie, God's mother, Eve's advocate. A Marian narrative of women's salvation (London: Continuum, 2002), 164-193.

58 Kelly, 'Exsultet,' 53 and 136. 
O certe necessarium Adae peccatum, quod Christi morte deletum est!

O felix culpa, quae talem ac tantum meruit habere Redemptorem!

O truly necessary sin of Adam that is destroyed by Christ's death!

O happy fault that deserved to have so great a Redeemer!

Fuchs traces this idea back to theologians as Ambrosius ('felix ruina, quae reparatur in melius', 'happy fall, that is repaired for the better'), who was traditionally credited as the author of the 'Exsultet', and Zeno of Verona ('o damnatio necessaria', 'o necessary damnation'). ${ }^{59}$ These phrases are not without theological problems. For example, abbot Hugh of Cluny (d. 1109) purged the phrases from the Cluniac Easter rite. ${ }^{60}$

The translation of the word necessarium is especially contested. Bonifatius Fisher has argued that, in medieval Latin, the word can be translated as nützlich ('useful' or 'serviceable'), followed later by Gerard Lukken's comparable suggestion of 'profitable;' Odo Casel suggested liebenswürdig ('love-worthy'), and Haines proposed 'inevitable', while others have pleaded for heilbringend ('salvation-bringing'). ${ }^{61}$ Other commentators have even tried to defuse the potential dogmatic bomb by classifying the necessarium Adae peccatum as a 'poetic hyperbole', a solution supported by Fuchs who stressed the poetic, rather than the dogmatic, character of the 'Exsultet'. ${ }^{62}$

The true 'sting' of this kind of reasoning is the subjectification of sin. If Mary's queenship is caused and justified by Adam's transgression, including the massive amount of other moral monstrosities, wars, and the suffering of countless individuals it has brought about, then

59 Fuchs, 'Exsultet,' 67 and 135.

${ }^{60}$ Barbara Newman, Medieval crossover. Reading the secular against the sacred (Indiana: Notre Dame Press, 2013), 14.

61 Bonifatius Fischer, ‘Ambrosius der Verfasser des Österlichen Exultet?,' Archiv für Liturgiewissenschaft 2 (1952): 69; Gerard Lukken, Original sin in the Roman liturgy (Leiden: Brill, 1973), 391-392; Odo Casel, 'Der österliche Lichtgesang der Kirche,' Liturgische Zeitschrift 4 (1931/32): 187; Victor Haines, 'Drawing evil with a happy face. The iconography of the Felix Culpa,' in The problem of evil. An intercultural exploration, ed. Sandra Wawrytko (Amsterdam: Rodopi, 2000), 82; G. Langgärtner, 'Bewusst beten. Das Osterlob “Exsultet”. Ein theologischer Kommentar,' in Weizenkorn Elemente zur Feier der Gemeindemesse. Lesejahr B, Heft 3, ed. H. Ritt (Stuttgart 1985), 158. Heinrich Zweck, 'Osterlobpreis und Taufe. Studien zu Struktur und Theologie des Exultet und anderer Osterpraeconien unter besonderer Berücksichtigung der Taufmotive (Frankfurt am Main: P. Lang, 1986), 61; Fischer, 'Ambrosius,' 96; Fuchs, 'Exsultet,' 70. 
what does this mean for the sins of individuals, and more pressingly, their moral value and/or judgement? If Adam's sin - unintentionally brought forth such a great blessing as the Incarnation was, then my own sins can - at least possibly - be the reason for greater good later on down the road. This re-frames sins not so much as evil deeds which are to be condemned, but as necessary, if not unpleasant, conditions for the realisation of a greater good, and which one should be considerate enough to not judge too negatively. This offers a problem to orthodoxy that was seldomly missed in mainstream Christian theology.

\section{The Marian 'Felix Culpa'}

The text of 'Adam lay ybounden' is a playful combination of official church theology and more or less officially sanctified legends and folk piety. The first strophe speaks about Adam being bound in the netherworld, from which he is only saved when Christ himself descends into it and saves him. The Descensus Christi is well-anchored within the Christian tradition, but lacks any scriptural base, only to be found in apocryphal texts. The content of the second strophe, about Adam taking the forbidden food, is - by contrast - very much grounded in scripture and as is its identification as an apple in the Christian tradition. Even though the poem mixes scriptural and traditional elements, it claims to be of the first kind by adding 'as clerics have found written in their book'. Also the idea of Mary being the queen of heaven (and earth) stems from the tradition and not from the Bible, as is that of the felix culpa.

It is precisely this mixture of Biblical, pious legends, and folk spirituality, half sanctioned, half opposed by official church doctrine and professional theologians, that gives the poem its specific charm. It taps into a larger narrative complex on the grand history of humankind, from the creation of the universe and the fall from paradise through the death and resurrection of Christ to the continuation of this state of renewed grace in the coronation of Mary as eternal queen. It is a history of grace, for which the poet praises God in the last sentence, converging all of scriptures and legends into one great liberation story. If humankind used to live in an era conquered by disgrace, through Christ's descensus it entered a new one under Mary's governance.

Folk songs and popular piety do not care too much about the finesses of academic theology or the subtleties of ecclesiastically condoned 
practices. They see on the stained-glass windows of the cathedrals Adam sinning with his apple in paradise, and Mary nurturing her baby Jesus, who is stretching out his arms to humankind whom he will later save by his death and resurrection. Christ has been replaced by his mother in this poetic history of salvation, by which the divine grace flows from God to humankind through Mary's loving care.

'Adam lay ybounden' is, last but not least, a tribute to the theological idea of the nexus mysteriorum, the idea that all Christian articles of faith are interlocked and interconnected. Creation, fall-from-grace, the Old Testament, Christ's death, descensus and resurrection, humankind's restatement into grace, Mary's queenship of heaven and earth: if one wants to understand any of the constituting parts, one has to understand its relationship to all the others. 'Adam lay ybounden' is a theological potpourri, a melting pot of parts and shades of the grand stories of the Christian salvational history.

Faculty of Catholic Theology, Tilburg University Warandelaan 2 5037 AB Tilburg

Netherlands E-mail:f.g.bosman@uvt.nl 